FERRY FERDIANTO, IWAN JUNAEDI, MULYONO

Argentine Curriculum in Covid-19 Pandemic

\title{
Argentine Curriculum in Covid-19 Pandemic
}

\author{
Ferry Ferdianto $^{*}$, Iwan Junaedi ${ }^{2}$, Mulyono ${ }^{2}$ \\ ${ }^{1}$ Program Studi Pendidikan Matematika, Universitas Negeri Semarang, Indonesia \\ ${ }^{1}$ Program Studi Pendidikan Matematika, Universitas Swadaya Gunung Jati, Indonesia \\ ${ }^{2}$ Program Studi Pendidikan Matematika, Universitas Negeri Semarang, Indonesia \\ *ferrymatematika@gmail.com
}

\begin{abstract}
ABSTRAK
Corona virus disease 2019 (Covid-19) mulai menyebar di negara Argentina pada bulan Maret 2020, berdasarkan data hingga 25 Agustus 2020, di Argentina tercatat lebih 350.000 orang terinfeksi virus corona -19 berada di peringkat 15 besar negara dengan kasus terbanyak,. Tujuan penulisan ini adalah untuk penyusunan pengembangan kurikulum di Argentina dalam menghadapi pandemic covid-19. Metode penelitian yang digunakan adalah literatur studi, pengumpulan informasi dan data melalui berbagai literatur, buku, jurnal, peraturan pemerintahan Argentina, hasil penelitian sebelumnya yang relevan. serta referensi lainnya, Adapun analisis yang dilakukan adalah proses penyusunan kurikulum di Argentina dalam menghadapi pandemic covid-19 dengan model penyusunan kurikulum Saylor, yang terdiri dari perencanaan kurikulum, implementasi kurikulum, dan evaluasi kurikulum. Pemerintah Argentina telah mengeluarkan beberapa peraturan dan kurikulum dalam menghadapi pandemic covid-19. Resolusi CFE No. 362/2020 keputusan yang mengatur Protokol Pendidikan Jarak Jauh, dengan Resolusi N ${ }^{\circ} 423 / 2020$ Kementerian Pendidikan Bangsa membentuk "Dewan Penasehat Perencanaan Pengembalian Saat Ini ke Ruang Kelas". Pada model Saylor, Alexander dan Lewis, dimana perubahan kurikulum dilaksanakan melalui tiga tahap, yaitu; tahap perancangan kurikulum, tahap implementasi kurikulum, dan tahap evaluasi kurikulum, perubahan kurikulum dilakukan untuk dapat menjamin para warga negaranya tetap mendapatkan Pendidikan.
\end{abstract}

Kata kunci: Covid-19, Kurikulum Argentina, Model Saylor.

\begin{abstract}
Corona virus disease 2019 (Covid-19) began to spread in Argentina in March 2020, based on data until August 25, 2020, in Argentina there were more than 350,000 people infected with the corona virus -19 , ranked in the top 15 countries with the most cases. The purpose of this paper is to prepare curriculum development in Argentina in the face of the COVID-19 pandemic. The research method used is literature study, collecting information and data through various literatures, books, journals, Argentine government regulations, relevant previous research results. as well as other references. The analysis carried out is the process of preparing the curriculum in Argentina in the face of the covid-19 pandemic with the Saylor curriculum formulation model, which consists of curriculum planning, curriculum implementation, and curriculum evaluation. The Argentine government has issued several regulations and curricula in dealing with the COVID-19 pandemic. CFE Resolution No. 362/2020 decree governing the Distance Education Protocol, with Resolution $N^{\circ} 423 / 2020$ the Ministry of Education of the Nation established the "Advisory Council on Current Return to Classroom Planning". In the Saylor, Alexander and Lewis model, curriculum changes are implemented in three stages, namely; the curriculum design stage, the curriculum implementation stage, and the curriculum evaluation stage, curriculum changes are made to ensure that citizens continue to receive education.
\end{abstract}

Key words: Covid-19, Argentinian Curriculum, Saylor's Model.

Received: 2021-07-21

/ Accepted: 2021-11-09

/ Published: 2021-11-15

\section{Introduction}

In Argentina now appears the term "quareternal" or eternal quarantine. The term was coined to describe the living conditions of the people of Argentina who have been in a strict and uninterrupted lockdown for more than five months. Argentina has become a country that carries out an uninterrupted and longest lockdown in the world, a lockdown that has lasted since March 2020 in Argentina has shaken the economic, educational, social and psychological life of the Argentinean community, The lockdown rules in Argentina are very strict. Residents in the 
Buenos Aires Metropolitan Area (AMBA) are only allowed to go out to shop for food, basic necessities and access nearby services, recreational and entertainment events are all closed and banned, the death rate in Argentina stands at 13.6 deaths per 100,000 population

Seeing these conditions, the Federal Council for Education must immediately make changes to the curriculum in the face of this condition, a curriculum that can ensure that its citizens continue to receive education. District officials and the supervisory board and principal are now in charge of system administration. Control by the central provincial government focuses on inputs and outputs, and not on how objectives are achieved. The group decides independently about the procedures for implementing the curriculum and school administration (Dussel et al., 2000). The Federal Council for Education issued decision $N^{\circ} 297 / 2020$ and its extension of Urgency $N^{\circ} 576 / 2020$ to contain and reduce the spread of the COVID-19 epidemic. That Urgency No. 576/2020 stipulates that face-to-face classes will remain suspended at all levels and gradually or alternately restart. CFE Resolution No. 362/2020 decree governing the Distance Education Protocol, with Resolution N ${ }^{\circ} 423 / 2020$ the Ministry of Education of the Nation established the "Advisory Council on Current Return to Classroom Planning". That this act was issued approved by CFE Resolution No. 1/07 and No. 362/2020, and CFE Resolution No. 364/2020 on Framework Protocols And Federal Guidelines For Return To Class Presentations In Compulsory Education And Higher Institutes by unanimous vote of all members of the body issued electronically in response to the ongoing epidemiological situation in the country. through and whose records are completed by the Secretariat. By looking at the policies and conditions that occurred it came to the conclusion that the aim of the curriculum change was to decentralize the definition of content for Argentine schools, devolving some of this responsibility to the provinces, schools and teachers (Gvirtz \& Beech, 2004).

In the education the curriculum is never fixed, this is because the curriculum must adapt to environmental conditions and the long-term goals to be achieved from a curriculum, designed by educators must provide opportunities for students to participate actively in learning (Prabowo \& Sunaryo, 2015). The curriculum is developed with various models of curriculum development, each curriculum development model has characteristics in the pattern of design, implementation, evaluation and follow-up in learning. In curriculum development, it can be identified on the basis of what will be achieved in the curriculum, such as alternatives that emphasize the needs of subjects, students, mastery of the competence of a job, community needs or social problems. Therefore, curriculum development needs to be carried out based on the right theory so that the resulting curriculum can be effective.

Curriculum planning is a plan of several small units in certain parts of a curriculum, Saylor, Alexander, and Lewis model Saylor, Alexander, and Lewis formulate the curriculum planning process as shown in Figure 1 (Lunenburg, 2011).

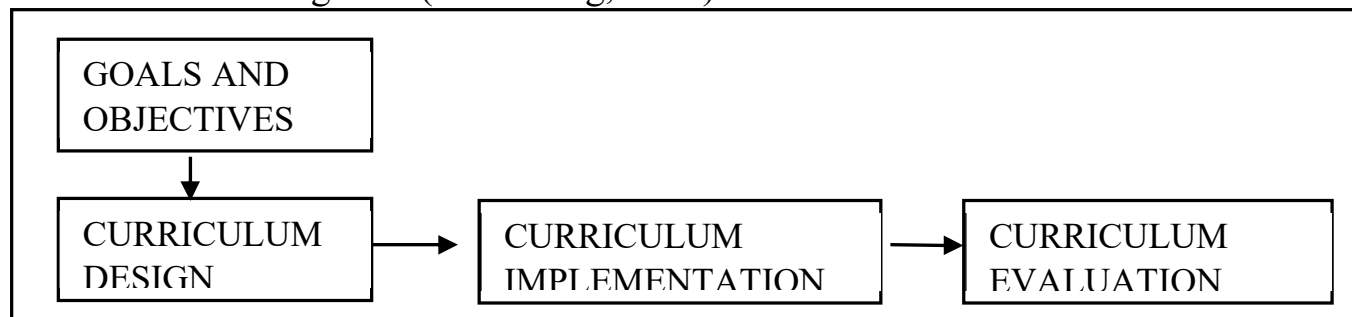

Figure 1. Saylor Model, Alexander, and Lewis 
In Figure 1 it can be seen that the Saylor, Alexander and Lewis curriculum development model consists of curriculum design, curriculum design that must pay attention to the goals and objectives to be achieved, after the curriculum is made the next step is the implementation of the curriculum applied in the teaching and learning process, the last step is evaluation of curriculum implementation (Anih, 2015).

Students are taught by math and science tutors in classes from the first year of high school (Grade 8), if not earlier. In some schools, students are taught by math and science tutors at the elementary level from Grade 6 or 7. Math lessons begin in kindergarten. In public primary schools, the city provides textbooks for students from Grades 1 to 7 , and teachers select textbooks from a list available online. While in private schools, teachers recommend textbooks. At secondary level, teachers are free to choose textbooks and usually prepare their own exercises and guidelines. Within the framework of the National Plan for Compulsory Teacher Education (Resolution No. 188/12, 2012-2016), the Ministry of Education makes the provision of laboratory and library equipment in public elementary schools universal. The previous program, Natural Sciences for All, initially distributed it to a group of beneficiary schools.

In 2004, the Secretary of Education of the City of Buenos Aires approved the current Curriculum in Elementary and Junior Secondary Grades, an adaptation of the 1986 curriculum for primary education (Resolution No. 365/SED/2004). At the secondary level, different types of schools share a core curriculum, which was established in 2009. The main types of secondary schools are: bachiller, liberal arts schools that offer the option to specialize in the upper classes in the social sciences, sciences, physics and mathematics, arts, sports, graphic arts, and pedagogy; commercial, school focused on accounting, finance, business, and economics; and technical-professional schools that offer vocational training in areas such as agriculture, electricity, mechanics and construction. In junior secondary, the curriculum is similar for each type of school with variations depending on the area of specialization of each school.

\section{Methods}

The method used in writing this article is literature study, collecting information and data through various literatures, books, journals, Argentine government regulations, relevant previous research results. as well as other references. The analysis carried out is the process of preparing the curriculum in the face of the COVID-19 pandemic with the Saylor curriculum formulation model. Starting with analyzing curriculum planning, starting with determining the main goals and specific educational goals to be achieved, from the curriculum plan that has been prepared, an analysis of the teaching plan is carried out, after implementation, the next analysis is evaluation analysis.

\section{Results and Discussion}

The Federal Education Council in the face of the COVID-19 pandemic immediately made changes to the curriculum, this was intended so that the education process for Argentineans could still be carried out. In the process of preparing curriculum changes referring to the model of Saylor, Alexander and Lewis, where curriculum changes are carried out through three stages, namely; curriculum design stage, curriculum implementation stage, and curriculum evaluation stage. 


\section{AlphaMath \\ Journal of Mathematics Education, 7(2) November 2021}

\section{Curriculum Design Stage}

There are three things that are related when designing a curriculum using the Saylor model, namely, objectives, objects, and fields. This model begins by identifying the main goals of education and specific goals. Saylor, Alexander, and Lewis classify goals into four domains, namely personal development, social competence, continuous learning skills, and specialization. Curriculum developers must determine learning opportunities for each domain, how and when learning opportunities are provided and choose areas to be developed in the curriculum, for example curriculum development based on the social pattern of an institution, or based on the relationship between student needs and interests.

The COVID-19 pandemic, which entered Argentina and entered into an extraordinary scenario in the history of the National Education System, required the suspension of children's attendance at school as usual. The suspension activities are aimed at saving lives of children, and maintaining social interactions that can accelerate the spread of the Covid-19 virus. Although face-to-face classes are no longer enforced, the learning process and learning opportunities for children must still be provided on an ongoing basis.

The Argentine government saw the situation issued Decree no. 297/2020 and complementary, social isolation, preventive and mandatory ones are established, which is why face-to-face classes are suspended in the Argentine Republic at all levels and vocational regulated by the National Education Act. In line with that, the issuance of Presidential Decree No. 576/2020, in order to contain and reduce the spread of the COVID-19 epidemic and its implementation is intended to maintain public health, adopt measures that are proportionate to the threats faced, sectorally, naturally and temporarily.

Perpes No 576/2020 stipulates that face-to-face classes will remain suspended at all levels and in all vocational areas until fully or partially, gradually or alternately restarted, and/or by region or geographic level or section or modality, prior approval of the relevant protocol., that the Ministry of National Education should establish for each level and modality the mechanisms and authorities that can order the resumption of face-to-face classes and approval of protocols, in accordance with applicable regulations.

Resolution CFE No. 362/2020 it approves the Remote Operations Protocol of this federal agency, which complements for all purposes the Operations Regulations approved by Resolution CFE No. 1 March 27 2020. Resolution CFE No. 364/2020 discusses the specifications and recommendations resulting from the application of the Framework Protocol in the context of Early Education, in areas where specifications are required due to the characteristics of the Level, followed by Reference: Resolution CFE No. 370/2020 Amendments to Resolution CFE No. 364/2020 FEDERAL EDUCATION COUNCIL that every private or public Educational Institution should take into account the following, 1) strengthen compliance with all "necessary conditions for risk stratification and determining the resumption of activities in schools" (point A of the Framework); 2) verify compliance with all requirements set out in the framework protocol approved by Resolution CFE No. 364/2020; 3 ) incorporate, where appropriate, analyzes of other conditions deemed relevant to address the peculiarities of local epidemiology and educational dynamics; and 4) determine the level of risk as a result of a combination of epidemiological indicators (point $\mathrm{C}$ of the Framework). For each planned risk category 
In line with Resolution No. 362/2020 also issued Reference decision: Resolution CFE No. 371/2020 - Technical Professional Education on specific protocols and recommendations for the realization of practice in the training environment of Professional Technical Education ETP (Workshops, Laboratories and Productive Spaces). Article 2.- Provide that the documents approved in article 1 discuss the specifications and recommendations resulting from the implementation of the Framework Protocol approved by Resolution CFE No. 364/20, in the context of Professional Technical Education, in the areas in which they are made Additional specifications are required due to the characteristics of the modalities

To establish common rules that allow for the arrangement of this extraordinary period, based on proven experience that can be contextualized and, as far as possible, conform to the current normative framework at the national and jurisdictional levels. That in this context it is necessary to agree on a federal framework that reflects on and validates the various situations that jurisdictions are currently experiencing in the context of these exceptions.

That is why it is necessary to approve the document "National Guidelines for setting up Training Systems in the context of preventive social isolation (ASPO), and preventive and mandatory social distancing (DISPO)" contained in Reference: Resolution CFE No. 373/2020, for federal guidance on updating the regulatory framework of approved jurisdictions on an exception basis, in the current epidemiological situation.

\section{Curriculum Implementation (Teaching and Learning Activities)}

The stages of implementing the curriculum according to Saylor are the stages in which to determine the methods and strategies that will be used to establish relationships and interact with students. The Republic of Argentina is a federal state consisting of 24 provinces. Each province is the seat of an education authority, usually a minister, and 24 ministers sit on the Federal Council of Education, headed by the national education minister. Provincial governments run schools and establish curricula, in accordance with very general national regulations regarding the structure and mission of the education system. Education authorities do not operate at the municipal level; each provincial ministry directly regulates schools in its province (Labate, 2007).

In the face of this pandemic, the Federal Education Council issued a Reference Decision: Resolution CFE No. 372/2020 - Teacher Training - Specific Framework Protocol. Decree No. 423/2020 of the Ministry of Education of the Nation established an "Advisory Board for Current Return to Classroom Planning" whose functions include: advising on the planning and implementation of general and federal regulations of scope, by the competent bodies, for the return of students, teachers, teaching staff and non-teaching staff to educational institutions of early, primary, secondary, and higher education, based on technical and scientific criteria, and taking into account the international experience and peculiarities and phases of social isolation, prevention and mandatory, as well as the evolution of pandemics in each jurisdiction.

In addition it is also necessary to agree on a set of work guidelines governing order in the activities inherent in the return to face-to-face classes, based on the criteria for sanitation, hygiene and safety, as well as the institutional and pedagogical organization in force during training systems that allow the return of face-to-face classes in training institutions teachers across the country. 
In Article 13. Resolution CFE No. 387/2021 on Teaching Planning. Teaching planning within the framework of the 2020-2021 pedagogical unit should include: (a) educational and training objectives that must be met at the end of the school year, (b) prioritizing and reorganizing the jurisdictional curriculum, within the framework of the 2020-2021 pedagogical unit. (c) the widest possible integration of fields, disciplines, subjects and/or curricular spaces, for the attainment of the training objectives, (d) specifically at the secondary level, greater curricular integration that allows a reduction in the number of teachers assigned to teach each group (based on the project) or integrated area rather than subject-based), concentrate the time burden and reduce the mobility of teachers between different schools, (e) the content taught, individual trajectories and levels of achievement achieved by students from each section and group, during pedagogical continuity in 2020 , (f) possible combinations and complementarities of face-toface and non-face-to-face work, articulation of activities to be developed in each agency and forms of monitoring and evaluation, (g) non-face-to-face schooling in the event that there are students who cannot attend school because it includes in at-risk groups or in cases where the epidemiological situation requires temporary cessation of face-to-face activities, and (h) shared responsibility and collaborative work between levels and modalities for the protection of the trajectory of students who remain hospitalized or at rest homes since before the pandemic and also for students who may suffer from diseases, not COVID-19, any time of the school year.

\section{Curriculum Evaluation}

In the evaluation step of the Saylor, Alexander, and Lewis model of curriculum development, there are several indicators that must be evaluated, namely, Evaluation of Curriculum Objectives and Evaluation of Learning (Instructional). As a result of implementing the curriculum during the COVID-19 pandemic and taking into account the increasing development of the population affected by COVID-19, the Federal Education Council, which continues to coordinate with Health authorities, issued Resolution CFE No. 387/2021.

In article 2. Resolution CFE No. 387/2021 Education activities by Epidemiological Risk Level - Health and education authorities and/or C.O.E. the provincial or equivalent provincial authority of each jurisdiction, shall decide on the resumption and maintenance of face-to-face educational activities in the urban agglomeration, party or department, city or place forming the jurisdiction, in accordance with the availability of health and risk information disaggregated in minimum geographic units and with considering the dynamism of the epidemiological situation. To do this, they must: 1) strengthen compliance with the "necessary conditions for risk stratification and determining the resumption of activities in schools" (point A of "Risk analysis and evaluation framework for the development of face-to-face activities and re-linking in schools" in the context of COVID-19 ", Annex to Federal Education Council Resolution No. $370 / 2020)$; 2) verify compliance with all requirements set out in the framework protocol approved by Federal Education Council Resolution No. 364/2020 and its amendments; 3) incorporate, where appropriate, analysis of other conditions deemed relevant to address the peculiarities of local epidemiology and educational dynamics; and 4) consider comprehensive sanitary and epidemiological analyzes of different urban agglomerations, districts or departments, cities or places, carried out within the framework of parameters and procedures epidemiology stipulated in the Decree of Need and Urgency No. 67/2021, and its amendments. (Point $\mathrm{C}$ of "Risk analysis and evaluation framework for the development of face-to-face activities and re-linking in schools in the context of COVID-19", Attachment of Resolution No. 370/2020 Federal Council of Education). 
Resolution CFE Decision No. 387/2021 in Article 1. General Principles. Prioritize the opening of schools and the resumption of face-to-face classes across the country in conditions of health insurance and community health care education, gradually, according to the epidemiological situation in small-scale geographic units in which it is possible to assess the existing sanitary and epidemiological risks. While for article 2 of the School Calendar. Endorsing that classes will start at all grades and modalities required on the date set in the school calendar of each jurisdiction under any form of school approved by Resolution No. 366/2020 Federal Board of Education: face-to-face, not face-to-face or combined.

Article 3. Form of School. Stipulates that in extraordinary situations caused by the pandemic, various forms of school will be implemented according to three conditions, namely face-toface, non-face-to-face, and combined.

Face to face, in this condition assumes regular attendance at school every day of the week at times determined by each jurisdiction. It can only be applied in schools where the relationship between the number of students and the physical space allows compliance with the physical distance established in the protocol. That for face-to-face teaching, not only classrooms but all available rooms in the building that have adequate dimensions and ventilation can be used, namely: laboratories, libraries, workshops, classrooms, multipurpose rooms (SUM), dining rooms, gyms , among others. Galleries, semi-enclosed terraces and outdoor spaces can also be used, depending on the configuration and climate

Non-face-to-face: assumes that all schools are conducted without attendance at face-to-face activities. It is provided for students who for health reasons belong to a risk group and cannot attend school in person and for students enrolled in schools where, by decision of the jurisdictional education and health authority, face-to-face activities cannot be activated.

Combined: student alternative work time with school attendance in face-to-face classes and educational activities in non-face-to-face situations mediated by different instruments and supports. It will be implemented in all cases where it is necessary to ensure the maintenance of basic norms of physical distancing, reducing the overcrowding of classrooms and school buildings. This will require organizing students into smaller groups according to different criteria and determining a regime of changing days and hours of school attendance for each group.

\section{Conclusion}

In this article, the Saylor, Alexander, and Lewis Model curriculum development model is presented by the Argentine ministry in dealing with the COVID-19 pandemic. Curriculum changes are based on several documents including the Framework Document of risk analysis and evaluation, Reference documents, Resolution documents, and management and control documents. Curriculum changes are made to ensure that its citizens continue to receive education. In the Saylor, Alexander and Lewis model, curriculum changes are implemented in three stages, namely; curriculum design stage, curriculum implementation stage, and curriculum evaluation stage.

\section{References}

Anih, E. (2015). Manajemen Implementasi Kebijakan Pengembangan Kurikulum di Perguruan Tinggi berbasis Kompetensi. Judika (Jurnal Pendidikan Unsika), 3(1).

Anih, E. (2015). Manajemen Implementasi Kebijakan Pengembangan Kurikulum di Perguruan 
Tinggi berbasis Kompetensi. Judika (Jurnal Pendidikan Unsika), 3(1).

Dokumen Referensi: Resolusi CFE No. 370/2020 - Modificatoria de la Resolusi CFE No. $364 / 202$

Dokumen Referensi: Resolusi CFE N 371/2020 - Educación Técnico Profesional

Dokumen Resolusi CFE N 372/2020 - Formación Docente - Protocolo Marco Específico

Dokumen Referensi: Resolusi CFE N 376/2020 - Protocolo Nivel Inicial

Dukumen Referensi: Resolusi CFE No. 377/2020 - Protocolo Modalidad Especial

Dokumen Manajemen dan pengendalian Covid-19 di lembaga pendidikan

Dokumen Resolusi CFE No. 373/2020 - Formación Docente - Lineamientos Nacionales para la regulación del Sistema Formador en contexto de aislamiento social preventivo (ASPO) y distanciamiento social preventivo y obligatorio (DISPO)

Dokumen Resolusi CFE N 388/2021 Bibliotecas Escolares

Dussel, I., Tiramonti, G., \& Birgin, A. (2000). Towards a new cartography of curriculum reform: reflections on educational decentralization in Argentina. Journal of Curriculum Studies, 32(4), 537-559.

Gvirtz, S., \& Beech, J. (2004). From the intended to the implemented curriculum in Argentina: Regulation and practice. Prospects, 34(3), 371-382.

Labate, H. (2007). Science education: a (pending) chapter in the curriculum transformation in Argentina. Prospects, 37(4), 469-488.

Lunenburg, F. C. (2011). Curriculum development: Inductive models. Schooling, 2(1), 1-8.

Prabowo, A., \& Sunaryo, S. (2015). Meningkatkan Partisipasi Aktif Mahasiswa Pada Mata Kuliah Analisis Kurikulum dan Materi Pembelajaran Matematika I Dengan Menggunakan Model Pembelajaran Kooperatif Tipe Students Team-Achievement Division (STAD). AlphaMath: Journal of Mathematics Education, 1(1). 